\title{
Brevibacterium salitolerans sp. nov., an actinobacterium isolated from salt-lake sediment
}

\author{
Correspondence \\ Xiao-Ping Zhang \\ zhangxiaopingphd@126.com \\ Li-Li Zhang \\ zhang63lyly@yahoo.com.cn or \\ guantongwei78@126.com
}

\author{
Tong-Wei Guan, ${ }^{1,2,3}$ † Ke Zhao, ${ }^{1} \dagger$ Jing Xiao, ${ }^{4}$ Ying Liu, ${ }^{3}$ Zhan-Feng Xia, ${ }^{2}$ \\ Xiao-Ping Zhang ${ }^{1}$ and Li-Li Zhang ${ }^{2}$
}
${ }^{1}$ Faculty of Resource and Environmental Sciences, Sichuan Agricultural University, Yaan 625000, PR China
${ }^{2}$ Key Laboratory of Protection and Utilization of Biological Resources in Tarim Basin of Xinjiang Production and Construction Corps, Tarim University, Alar, Xinjiang 843300, PR China
${ }^{3}$ State Key Laboratory of Microbial Resources, Institute of Microbiology, Chinese Academy of Sciences, Beijing 100101, PR China
${ }^{4}$ Key Laboratory of Marine Biological Resources, Third Institute of Oceanography, State Oceanic Administration, Xiamen, Fujian 361005, PR China

\begin{abstract}
A novel bacterium, designated TRM $415^{\top}$, belonging to the genus Brevibacterium, was isolated from a sediment sample from a salt lake in Xinjiang province, China. Comparative 16S rRNA gene sequence analysis indicated that strain TRM $415^{\top}$ was phylogenetically most closely related to Brevibacterium album YIM $90718^{\top}$ ( $98.4 \%$ sequence similarity) and had low similarity $(<95.5 \%)$ to other species of the genus Brevibacterium; however, DNA-DNA hybridization studies between strain TRM $415^{\top}$ and B. album YIM $90718^{\top}$ showed only $41.3 \%$ relatedness. Strain TRM $415^{\top}$ possessed meso-diaminopimelic acid as the diagnostic cell-wall diamino acid, $\mathrm{MK}-8\left(\mathrm{H}_{2}\right)$ as the major menaquinone and polar lipids including phosphatidylglycerol and diphosphatidylglycerol.

The major fatty acids were anteiso- $\mathrm{C}_{17: 0}$ and anteiso- $\mathrm{C}_{15: 0}$. The genomic DNA $\mathrm{G}+\mathrm{C}$ content was $69 \mathrm{~mol} \%$. Based on the evidence from this polyphasic study, strain TRM $415^{\top}$ represents a novel species of the genus Brevibacterium, for which the name Brevibacterium salitolerans sp.

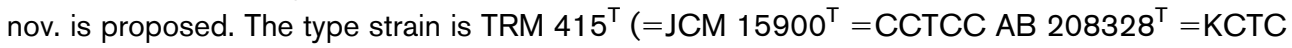
$\left.19616^{\top}\right)$.
\end{abstract}

The genus Brevibacterium was first described by Breed (1953) with Brevibacterium linens as the type species; the description was later emended by Collins et al. (1980). At the time of writing, the genus Brevibacterium contained 21 species with validly published names. In the present study, an actinobacterial isolate, designated TRM $415^{\mathrm{T}}$, from a sediment sample collected from Lop Nur salt lake in Xinjiang province, north-west China, was investigated by means of a polyphasic taxonomic approach. The lake environment and precise sampling site location were described previously (Guan et al., 2010).

The sample was isolated on GT2 medium using a 10-fold dilution series method with incubation at $37{ }^{\circ} \mathrm{C}$. The GT2 medium contained $\left(\mathrm{g} \mathrm{l}^{-1}\right)$ : glucose $(10)$, yeast extract (1),

†These authors contributed equally to this work.

The GenBank/EMBL/DDBJ accession number for the 16S rRNA gene sequence of Brevibacterium salitolerans TRM $415^{\top}$ is GU117109.

A transmission electron micrograph and a lipid profile of cells of strain TRM $415^{\top}$ and a phylogenetic tree based on maximum-likelihood analysis of $16 \mathrm{~S}$ rRNA gene sequences are available as supplementary material with the online version of this paper. tryptone (0.5), $\mathrm{CaCO}_{3}(1), \mathrm{NaCl}$ (50), $\mathrm{KCl}$ (30), $\mathrm{MgCl}_{2}$ (10) and agar (16). The medium was adjusted to $\mathrm{pH} 7.0-$ 7.5. The organism was grown and maintained on modified ISP 5 medium (Shirling \& Gottlieb, 1966) with $2 \%(\mathrm{w} / \mathrm{v})$ $\mathrm{NaCl}, 1 \%(\mathrm{w} / \mathrm{v}) \mathrm{KCl}$ and $0.5 \%(\mathrm{w} / \mathrm{v}) \mathrm{MgCl}_{2}$. Biomass for chemical and molecular studies was determined by cultivation in flasks containing the above modified ISP 5 medium and incubation with shaking ( 180 r.p.m.) at $37{ }^{\circ} \mathrm{C}$ for 1 week.

Cell morphology and motility were examined by optical (Olympus BX40) and transmission electron (JEM-1230) microscopy. Gram staining was carried out using the standard Gram reaction method and was confirmed by using the $\mathrm{KOH}$ lysis test (Cerny, 1978). The ability of strain TRM $415^{\mathrm{T}}$ to grow was tested at $4-55{ }^{\circ} \mathrm{C}$ and $\mathrm{pH} 4-11$ as described by $\mathrm{Xu}$ et al. (2005) and tolerance to concentrations of $0-25 \%(\mathrm{w} / \mathrm{v}) \mathrm{NaCl}$ was tested using ISP 5 as the basal medium. Antimicrobial susceptibility tests were performed using antimicrobial compounds (BBL) according to Mata et al. (2002). Carbon source utilization tests were carried out using 95 substrates in GP2 MicroPlates of the Microlog system (Biolog). The physiological properties 
of strain TRM $415^{\mathrm{T}}$ were tested by using the API Coryne system (bioMérieux) according to the manufacturer's instructions and by using the media and methods of Gordon et al. (1974). Detailed morphological, cultural and physiological properties of strain TRM $415^{\mathrm{T}}$ are given in Table 1 and in the species description.

The type of diamino acid in cell-wall hydrolysates of strain TRM $415^{\mathrm{T}}$ was determined following methods described previously (Lee, 2006; Staneck \& Roberts, 1974). Identification of the cell-wall sugars in whole-cell hydrolysates was performed as described by Hasegawa et al. (1983). The absence of mycolic acids was demonstrated with TLC (Minnikin et al., 1980). Polar lipids were extracted, examined by two-dimensional TLC and identified using the procedures of Minnikin et al. (1984). Menaquinones were extracted using the method of Collins et al. (1977) and analysed by HPLC (Groth et al., 1997). The menaquinones detected included MK-8 $\left(\mathrm{H}_{2}\right)$ (64.7\%), MK-7 $\left(\mathrm{H}_{2}\right)$ (23.1\%), MK6( $\left.\mathrm{H}_{2}\right)$ (6.8\%), MK-8 (3.4\%), MK-7 (1.5\%) and MK-6
$(0.6 \%)$. The major fatty acids were anteiso- $\mathrm{C}_{17: 0}(43.8 \%)$ and anteiso- $\mathrm{C}_{15: 0}(30.3 \%)$. Cellular fatty acid composition was determined as described by Sasser (1990) using the Microbial Identification System (MIDI). The genomic DNA $\mathrm{G}+\mathrm{C}$ content of strain TRM $415^{\mathrm{T}}$ was determined by using the HPLC method (Mesbah et al., 1989). Results of the above experiments are reported in the species description and in Tables 1 and 2. Biomass for chemotaxonomic studies was obtained by growing strain TRM $415^{\mathrm{T}}$ in flasks containing ISP 5 liquid medium with $2 \%(\mathrm{w} / \mathrm{v}) \mathrm{NaCl}, 1 \%(\mathrm{w} / \mathrm{v}) \mathrm{KCl}$ and $0.5 \%(\mathrm{w} / \mathrm{v}) \mathrm{MgCl}_{2}$ with shaking at $37{ }^{\circ} \mathrm{C}$ for 3 days.

Genomic DNA of strain TRM $415^{\mathrm{T}}$ was extracted from cells grown on modified ISP 5 medium (as above) for 4 days at $37{ }^{\circ} \mathrm{C}$ and used as a template for subsequent PCR amplification. Reaction conditions and amplification protocols were used as described by Li et al. (2007). Multiple sequence alignments with closely related members of the genus Brevibacterium and sequence similarity calculations were carried out using the CLUSTAL_X program (Thompson

Table 1. Differential characteristics of strains TRM $415^{\top}$ and B. album YIM $90718^{\top}$

Strains: 1, TRM $415^{\mathrm{T}}$; 2, B. album YIM $90718^{\mathrm{T}}$

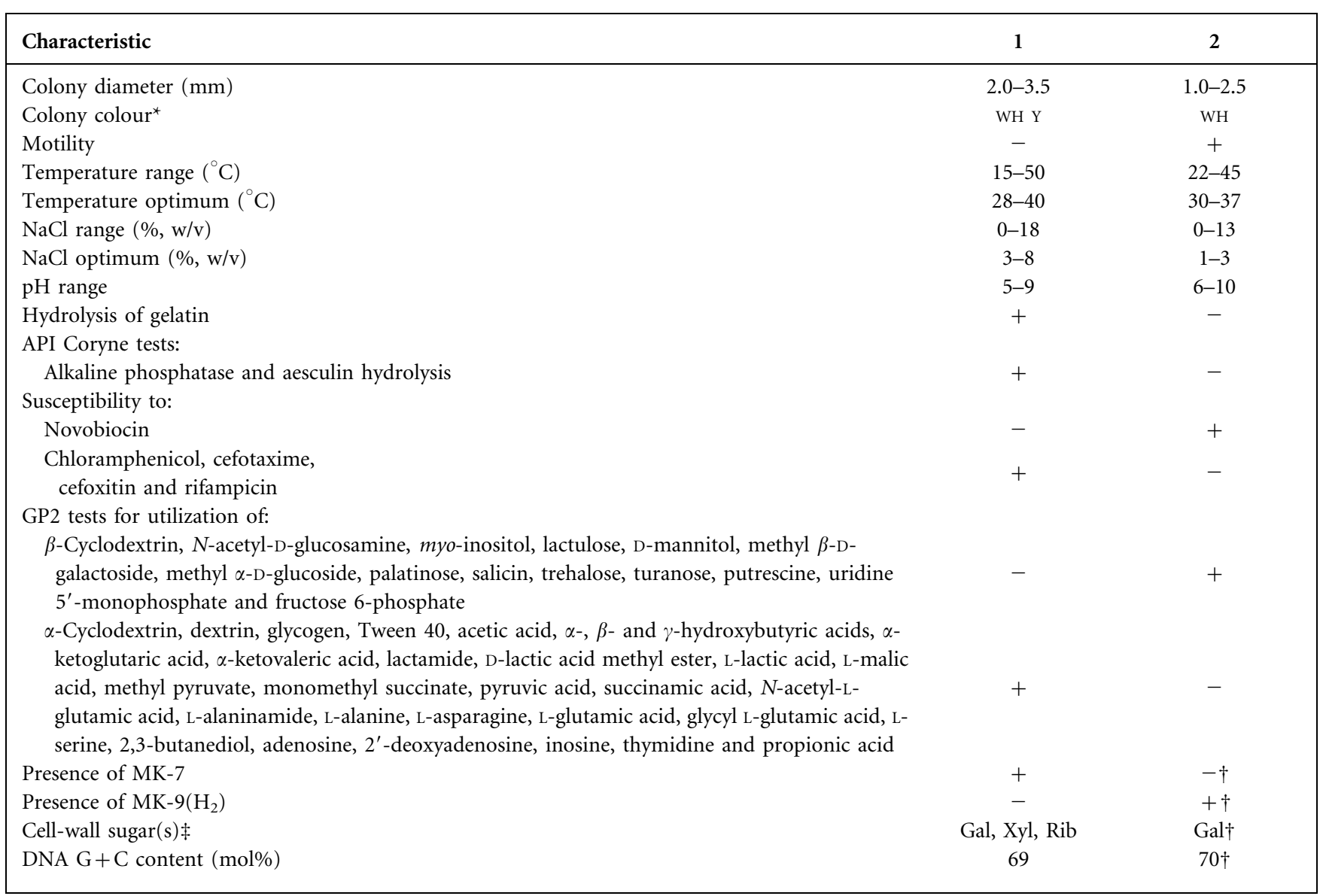

${ }^{*}$ WH, white; WH Y, whitish-yellow.

$\dagger$ Data from Tang et al. (2008); data from the current study were obtained using the same experimental conditions.

$\ddagger$ Gal, galactose; Xyl, xylose; Rib, ribose. 
Table 2. Cellular fatty acid compositions (\%) of strains TRM $415^{\top}$ and B. album YIM $90718^{\top}$

Strains: 1, TRM $415^{\mathrm{T}} ; 2$, B. album YIM $90718^{\mathrm{T}}$. Fatty acids that account for less than $1.0 \%$ of the total fatty acids in the two strains are not shown. Data are from this study and from Tang et al. (2008). NR, Not reported.

\begin{tabular}{|lcc|}
\hline Fatty acid & $\mathbf{1}$ & $\mathbf{2}$ \\
\hline iso- $\mathrm{C}_{14: 0}$ & 0.4 & $\mathrm{NR}$ \\
iso- $_{15: 0}$ & 11.0 & 12.3 \\
anteiso- $\mathrm{C}_{15: 0}$ & 30.3 & 58.7 \\
iso- $_{16: 0}$ & 9.9 & 7.2 \\
$\mathrm{C}_{16: 0}$ & 0.2 & $\mathrm{NR}$ \\
iso- $\mathrm{C}_{17: 0}$ & 4.3 & $\mathrm{NR}$ \\
anteiso- & & 19.0 \\
\hline
\end{tabular}

et al., 1997). Phylogenetic trees were constructed by the neighbour-joining (Saitou \& Nei, 1987) and maximumparsimony (Fitch, 1971) methods using the MEGA 3 program (Kumar et al., 2004) and maximum-likelihood phylogenetic trees were constructed (Felsenstein, 1981) with the PHYLIP 3.6 program. The topology of the resultant phylogenetic trees was evaluated by bootstrap resampling with 1000 replicates (Felsenstein, 1985). The results indicated that strain TRM $415^{\mathrm{T}}$ clustered within the genus Brevibacterium and exhibited the closest phylogenetic affinity (Fig. 1) and highest sequence similarity to

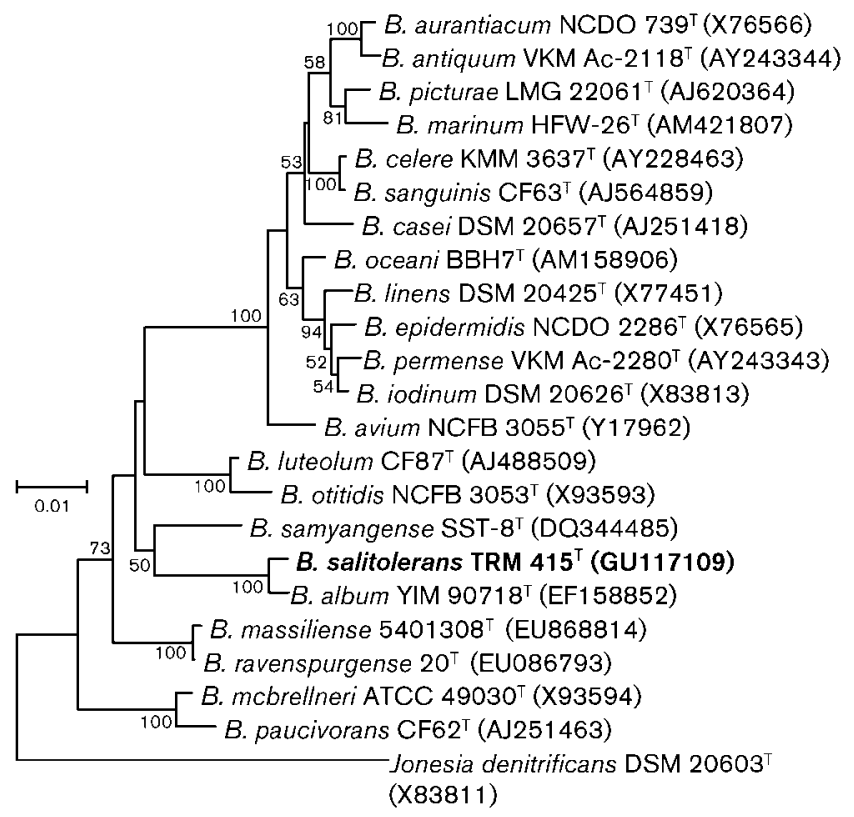

Fig. 1. Neighbour-joining tree based on 16S rRNA gene sequences, showing the phylogenetic relationships between the novel isolate TRM $415^{\top}$ and related taxa. Bootstrap values are percentages based on 1000 replicates; values $>50 \%$ are shown. Bar, 0.01 substitutions per nucleotide position.
Brevibacterium album YIM $90718^{\mathrm{T}}$ (98.4\%) with low similarity $(<95.5 \%)$ to other species of the genus Brevibacterium. Genomic hybridization experiments between strain TRM $415^{\mathrm{T}}$ and B. album YIM $90718^{\mathrm{T}}$ were performed by using the method described by $\mathrm{He}$ et al. (2005). Strain TRM $415^{\mathrm{T}}$ and B. album YIM $90718^{\mathrm{T}}$ showed $41.3 \%$ DNA-DNA relatedness to each other. Considering $70 \%$ DNA-DNA relatedness as the cut-off point for species delineation (Wayne et al., 1987) and based on the differences in the phenotypic characteristics and the chemotaxonomic and phylogenetic data observed between the two strains, strain TRM $415^{\mathrm{T}}$ represents a novel species of the genus Brevibacterium, for which the name Brevibacterium salitolerans sp. nov. is proposed.

\section{Description of Brevibacterium salitolerans sp. nov.}

Brevibacterium salitolerans (sa.li.to'.le.rans. L. n. sal, salis salt; L. part. adj. tolerans tolerating; N.L. part. adj. salitolerans salt tolerating, originating from a saline habitat).

Cells are Gram-reaction-positive, aerobic, non-motile rods, approximately $1.3-1.8 \times 0.6-1.0 \mu \mathrm{m}$. Colonies are 2.0$3.5 \mathrm{~mm}$ in diameter, smooth, circular and whitish-yellow when grown, in the dark or in the light, on ISP 5 medium with $2 \%(\mathrm{w} / \mathrm{v}) \mathrm{NaCl}, 1 \%(\mathrm{w} / \mathrm{v}) \mathrm{KCl}$ and $0.5 \%(\mathrm{w} / \mathrm{v})$ $\mathrm{MgCl}_{2}$ for 5 days. An apparent rod-coccus growth cycle is not observed after 5 days of growth. Growth occurs at 15$50{ }^{\circ} \mathrm{C}$ (optimum $28-40{ }^{\circ} \mathrm{C}$ ), at $\mathrm{pH} 5-9$ (optimum $\mathrm{pH} 7.0$ $7.5)$ and in concentrations of $0-18 \%(\mathrm{w} / \mathrm{v}) \mathrm{NaCl}$ [optimum $3-8 \%(\mathrm{w} / \mathrm{v}) \mathrm{NaCl}$. No growth occurs at 10 or $52{ }^{\circ} \mathrm{C}$ or in $20 \%(\mathrm{w} / \mathrm{v}) \mathrm{NaCl}$. Oxidase-negative and catalase-positive. Nitrate is reduced to nitrite. Gelatin is hydrolysed but Tweens 20, 60 and 80 and starch are not. Negative for milk coagulation and peptonization, cellulose hydrolysis, production of $\mathrm{H}_{2} \mathrm{~S}$ and methyl red and Voges-Proskauer tests. In the API Coryne system, tests are positive for pyrazinamidase, pyrrolidonyl arylamidase, alkaline phosphatase and $\beta$-glucosidase (aesculin hydrolysis) activities, gelatin hydrolysis and acid production from D-ribose; tests are negative for nitrate reduction, $\beta$-glucuronidase, $\beta$-galactosidase, $N$-acetyl- $\beta$-glucosaminidase, $\alpha$-glucosidase and urease activities and acid production from D-glucose, Dxylose, D-mannitol, maltose, lactose, sucrose and glycogen. The following substrates are utilized: L-fucose, D-gluconic acid, Tween 80, D-malic acid, succinic acid, D-alanine, L-alanyl glycine, $\alpha$-cyclodextrin, dextrin, glycogen, Tween 40, acetic acid, $\alpha-, \beta$ - and $\gamma$-hydroxybutyric acids, $\alpha$ ketoglutaric acid, $\alpha$-ketovaleric acid, lactamide, D-lactic acid methyl ester, L-lactic acid, L-malic acid, methyl pyruvate, monomethyl succinate, propionic acid, pyruvic acid, succinamic acid, $\mathrm{N}$-acetyl-L-glutamic acid, L-alaninamide, L-alanine, L-asparagine, L-glutamic acid, glycyl Lglutamic acid, L-serine, 2,3-butanediol, adenosine, 2'deoxyadenosine, inosine and thymidine. The following substrates are not utilized: $\beta$-cyclodextrin, $N$-acetyl-Dglucosamine, myo-inositol, lactulose, D-mannitol, methyl 
$\beta$-D-galactoside, methyl $\alpha$-D-glucoside, palatinose, L-rhamnose, salicin, trehalose, turanose, putrescine, uridine $5 '$-monophosphate, fructose 6-phosphate, inulin, mannan, $N$-acetyl- $\beta$-D-mannosamine, amygdalin, L-arabinose, D-arabitol, arbutin, cellobiose, D-fructose, D-galactose, D-galacturonic acid, gentiobiose, $\alpha$-D-glucose, lactose, maltose, D-mannose, melezitose, melibiose, methyl $\alpha$-D-galactoside, 3-methyl glucose, methyl $\beta$-D-glucoside, methyl $\alpha$-D-mannoside, D-psicose, raffinose, D-ribose, sedoheptulosan, D-sorbitol, stachyose, sucrose, D-tagatose, xylitol, D-xylose, p-hydroxyphenylacetic acid, L-pyroglutamic acid, glycerol, uridine, adenosine 5'-monophosphate, thymidine 5'-monophosphate, glucose 1-phosphate, glucose 6 -phosphate and DL- $\alpha$-glycerol phosphate. Susceptible to ( $\mu \mathrm{g}$ unless stated otherwise) streptomycin (10), amoxicillin (25), chloramphenicol (30), cefoxitin (30), kanamycin (30), nalidixic acid (30), nitrofurantoin (300), ampicillin (10), sulfamide (250), cefotaxime (30), erythromycin (15), polymyxin B (300 UI), rifampicin (30) and carbenicillin (100), but resistant to tobramycin (10) and trimethoprim-sulfamethoxazole (1.25-23.75). Whole-cell hydrolysates contain meso-diaminopimelic acid. Mycolic acids are absent. Cell-wall sugars contain galactose, xylose and ribose and the phospholipids include phosphatidylglycerol and diphosphatidylglycerol. The menaquinones are MK- $8\left(\mathrm{H}_{2}\right)$, MK- $7\left(\mathrm{H}_{2}\right)$, MK$6\left(\mathrm{H}_{2}\right)$, MK-8, MK-7 and MK-6. The major fatty acids are anteiso- $\mathrm{C}_{17: 0}$ and anteiso- $\mathrm{C}_{15: 0}$. The genomic DNA $\mathrm{G}+\mathrm{C}$ content of the type strain is $69 \mathrm{~mol} \%$.

The type strain, TRM $415^{\mathrm{T}}$ (=JCM $15900^{\mathrm{T}}=$ CCTCC AB $208328^{\mathrm{T}}=$ KCTC $19616^{\mathrm{T}}$ ), was isolated from a soil sediment sample from a hypersaline lake habitat in Xinjiang province, north-west China.

\section{Acknowledgements}

The authors are grateful to Professor Dr Wen-Jun Li (Laboratory for Conservation and Utilization of Bio-resources, Yunnan University, Kunming, Yunnan, PR China) for providing the type strain B. album YIM $90718^{\mathrm{T}}$. This research was supported by the National Natural Science Foundation of China (project numbers 30660005 and 30570062), the Key Project for Department of Science and Technology of Ministry of Education of China (project no. 209145), The Foundation of National Science Program of China (project no. 30570062), the Opening Project by State Key Laboratory of Microbial Resources, Institute of Microbiology, Chinese Academy of Sciences (project no. SKLMR-20090603), the Opening Project by Key Laboratory of Protection and Utilization of Biological Resources in Tarim Basin of Xinjiang Production \& Construction Corps (project no. BR0803) and the Program of the Higher Education Institution of Xinjiang (project no. XJEDU2005G07).

\section{References}

Breed, R. S. (1953). The Brevibacteriaceae fam. nov. of order Eubacteriales. Rias Commun VI Congr Int Microbiol Roma 1, 13-14.

Cerny, G. (1978). Studies on the aminopeptidase test for the distinction of gram-negative from gram-positive bacteria. Eur $J$ Appl Microbiol Biotechnol 5, 113-122.
Collins, M. D., Pirouz, T., Goodfellow, M. \& Minnikin, D. E. (1977). Distribution of menaquinones in actinomycetes and corynebacteria. J Gen Microbiol 100, 221-230.

Collins, M. D., Jones, D., Keddie, R. M. \& Sneath, P. H. A. (1980). Reclassification of Chromobacterium iodinum (Davis) in a redefined genus Brevibacterium (Breed) as Brevibacterium iodinum nom. rev., comb. nov. J Gen Microbiol 120, 1-10.

Felsenstein, J. (1981). Evolutionary trees from DNA sequences: a maximum likelihood approach. J Mol Evol 17, 368-376.

Felsenstein, J. (1985). Confidence limits on phylogenies: an approach using the bootstrap. Evolution 39, 783-791.

Fitch, W. M. (1971). Toward defining the course of evolution: minimum change for a specific tree topology. Syst Zool 20, 406416.

Gordon, R. E., Barnett, D. A., Handerhan, J. E. \& Pang, C. H.-N. (1974). Nocardia coeliaca, Nocardia autotrophica, and the nocardin strain. Int J Syst Bacteriol 24, 54-63.

Groth, I., Schumann, P., Rainey, F. A., Martin, K., Schuetze, B. \& Augsten, K. (1997). Demetria terragena gen. nov., sp. nov., a new genus of actinomycetes isolated from compost soil. Int J Syst Bacteriol 47, 1129-1133.

Guan, T.-W., Xiao, J., Zhao, K., Luo, X.-X., Zhang, X.-P. \& Zhang, L.-L. (2010). Halomonas xinjiangensis sp. nov., a halotolerant bacterium isolated from a salt lake. Int J Syst Evol Microbiol 60, 349-352.

Hasegawa, T., Takizawa, M. \& Tanida, S. (1983). A rapid analysis for chemical grouping of aerobic actinomycetes. J Gen Appl Microbiol 29, 319-322.

He, L., Li, W., Huang, Y., Wang, L., Liu, Z., Lanoot, B., Vancanneyt, M. \& Swings, J. (2005). Streptomyces jietaisiensis sp. nov., isolated from soil in northern China. Int J Syst Evol Microbiol 55, 1939-1944.

Kumar, S., Tamura, K. \& Nei, M. (2004). MEGA3: integrated software for molecular evolutionary genetics analysis and sequence alignment. Brief Bioinform 5, 150-163.

Lee, S. D. (2006). Brevibacterium samyangense sp. nov., an actinomycete isolated from a beach sediment. Int $J$ Syst Evol Microbiol 56, 1889-1892.

Li, W.-J., Xu, P., Schumann, P., Zhang, Y.-O., Pukall, R., Xu, L.-H., Stackebrandt, E. \& Jiang, C.-L. (2007). Georgenia ruanii sp. nov., a novel actinobacterium isolated from forest soil in Yunnan (China), and emended description of the genus Georgenia. Int J Syst Evol Microbiol 57, 1424-1428.

Mata, J. A., Martínez-Cánovas, M. J., Quesada, E. \& Béjar, V. (2002). A detailed phenotypic characterization of the type strains of Halomonas species. Syst Appl Microbiol 25, 360-375.

Mesbah, M., Premachandran, U. \& Whitman, W. B. (1989). Precise measurement of the $\mathrm{G}+\mathrm{C}$ content of deoxyribonucleic acid by highperformance liquid chromatography. Int J Syst Bacteriol 39, 159167.

Minnikin, D. E., Hutchinson, I. G., Caldicott, A. B. \& Goodfellow, M. (1980). Thin-layer chromatography of methanolysates of mycolic acid-containing bacteria. J Chromatogr A 188, 221-233.

Minnikin, D. E., O’Donnell, A. G., Goodfellow, M., Alderson, G., Athalye, M., Schaal, A. \& Parlett, J. H. (1984). An integrated procedure for the extraction of bacterial isoprenoid quinones and polar lipids. J Microbiol Methods 2, 233-241.

Saitou, N. \& Nei, M. (1987). The neighbor-joining method: a new method for reconstructing phylogenetic trees. Mol Biol Evol 4, 406425.

Sasser, M. (1990). Identification of bacteria by gas chromatography of cellular fatty acids, MIDI Technical Note 101. Newark, DE: MIDI Inc. 
Shirling, E. B. \& Gottlieb, D. (1966). Methods for characterization of Streptomyces species. Int J Syst Bacteriol 16, 313-340.

Staneck, J. L. \& Roberts, G. D. (1974). Simplified approach to identification of aerobic actinomycetes by thin-layer chromatography. Appl Microbiol 28, 226-231.

Tang, S.-K., Wang, Y., Schumann, P., Stackebrandt, E., Lou, K., Jiang, C.-L., Xu, L.-H. \& Li, W.-J. (2008). Brevibacterium album sp. nov., a novel actinobacterium isolated from a saline soil in China. Int J Syst Evol Microbiol 58, 574-577.

Thompson, J. D., Gibson, T. J., Plewniak, F., Jeanmougin, F. \& Higgins, D. G. (1997). The CLUSTAL_X windows interface: flexible strategies for multiple sequence alignment aided by quality analysis tools. Nucleic Acids Res 25, 4876-4882.

Wayne, L. G., Brenner, D. J., Colwell, R. R., Grimont, P. A. D., Kandler, O., Krichevsky, M. I., Moore, L. H., Moore, W. E. C., Murray, R. G. E. \& other authors (1987). International Committee on Systematic Bacteriology. Report of the ad hoc committee on reconciliation of approaches to bacterial systematics. Int J Syst Bacteriol 37, 463-464.

Xu, P., Li, W.-J., Tang, S.-K., Zhang, Y.-O., Chen, G.-Z., Chen, H.-H., Xu, L.-H. \& Jiang, C.-L. (2005). Naxibacter alkalitolerans gen. nov., sp. nov., a novel member of the family Oxalobacteraceae isolated from China. Int J Syst Evol Microbiol 55, 1149-1153. 